レーザーコンパス

核融合基礎研究の初期の思い出

岡田実*

\title{
Minoru OKADA*
}

爱読した小説でも, 年を経て, 読み返えすと 年令の影響や世情の移り変りを反映して, 感興 に違いを生じる。私は半世紀あまり謡曲の稽古 をしているが学生時代には遮二無二声を出し, 内容などほとんど気にしなかった。ところがこ の頃稽古をし直すといろいろ新しいことが判る のである。

核融合の基礎実駼でも私の研究室で着手した 1956年の初めには，実用より気宇壮大な理想を かかげていた。しかし今は違う。エネルギー資 源の乏しい日本の将来にとっては，太陽熱の利 用なども考えられ，寒験されているが，大量工 ネルギーを得るに核融合エネルギーの平和利用 に成功する程国民生活に大きい貢献はないと私 は思う。

核融合エネルギーの平和利用に成功すれば， 200カイリ水域はもとより太平洋の虍大な水量の $\frac{1}{6000}$ が重水でエネルギー源となる。したがって 現在の中東産油国より豊富なエネルギー資源国 に日本が変貌するのである。日本の南岸を洗う 黒潮の流れも莫大なエネルギーの流れとして見 られるであるう。

しかし核融合エネルギー平和利用が成功した ときは利用に厳しい制限をつけて過剩消費で人 類の生存を脅かすことのないように注意を鮕起 しておきたいと思う。

さて核融合基礎研究・初期の思い出を拾って 兒よう。

1955年に第 1 回原子力平和利用国際会議がジ
ユネーブで開催された。私はチューリッヒで開 かれた第 8 回国際溶接学会年次大会に出席して いた。両会議はほとんど同時期であった。

原子力会議で議長であった故バーバ博士が核 融合反応は20年以内に制御されるようになるだ ろうといって，世界の注目を引いた。私はその 会議に出た訳でなくスイスにいた友達からその ことを聞いたのである。しかしそのときは溶接 学会への出席のため静かに考える㗇がなかった。 また 20 年先といわれるとはるか未来のことのよ うに思えた。ただ集中度の高いエネルギー源と してプラズマに関心をもったのである。

新しい溶接熱源を開発しなければ溶接技術の 高精度化も高能率化もできなと思っていたの で時間がたつに従ってプラズマに関心を深めた のであった。

ところが帰国後まもなく石谷博士と有安君か ら核融合基礎実験をやるべきだと针説された。 今のようにエネルギー問題が注目されないで九 州, 北海道の黒ダイヤに礼讃の余韻が残ってい た時であった。私はまず私の研究室で荒田・有 安両教官, 西口, 丸尾両大学院生と相談実験を 始めることにした。(今四君は皆教授) そして考 えた。日本は従来一方的に海外の科学技術をと り入れて来た。原子力 (分裂反応) の利用にも 宇宙科学にも欧米との格差は問題にならない。 石谷君らのいうように巨大科学技術で残されて いるものは核融合エネルギ一の利用と生命科学 くらいである。

*大阪大学名举教授 
しかも人類は水爆実騟で核融合により巨大な エネルギーの発生を実験ずみである。またわれ われの地球に大量のエネルギーを供給している 太陽熟も核融合により発生するエネルギーであ るという。成否は別にしても世界の学界に酬い るためにも努力しようと思った。

そこで20KJのコンデンサーから始め, 科学研 究費をうけて $100 \mathrm{KJ}$ 電源をもつ值線ピンチ型 実験装置を作り，稀薄重水素中で瞬時電流 100 万アンペアを流し，ピンチの形成を超高速流し
カメラで撮影，また中性子の放出，X線の放射 を確認し，1958年2月8日第2 回原子カシンポ ジウムで発表したのである。間もなく衆議院科 学技術委員会に参考人として出席, 核融合研究 の必要性について証言した。

その後原子力娄員会核融合部会でA B 計画が 認められた。大阪大学では私達の後のプラズマ 関係は伊藤博教授らによって続けられ，別に山 中千代衛教授らによってレーザー核融合㥶験研 究が強力に進められていることは誠に喜ばしい ことである。 